\title{
Flavobacterium daejeonense sp. nov. and Flavobacterium suncheonense sp. nov., isolated from greenhouse soils in Korea
}

Correspondence

Soon-Wo Kwon

swkwon@rda.go.kr

\section{Byung-Yong Kim, ${ }^{1}$ Hang-Yeon Weon, ${ }^{2}$ Sylvie Cousin, ${ }^{3}$ Seung-Hee Yoo, ${ }^{1}$ Soon-Wo Kwon, ${ }^{1}$ Seung-Joo Go ${ }^{1}$ and Erko Stackebrandt ${ }^{3}$}

\begin{abstract}
1,2Korean Agricultural Culture Collection (KACC), Microbial Genetics Division, National Institute of Agricultural Biotechnology ${ }^{1}$ and Applied Microbiology Division, National Institute of Agricultural Science and Technology ${ }^{2}$, Rural Development Administration (RDA), Suwon 441-707, Republic of Korea

${ }^{3}$ Deutsche Sammlung von Mikroorganismen und Zellkulturen $\mathrm{GmbH}$, Mascheroder Weg $1 \mathrm{~b}$, D-38124 Braunschweig, Germany
\end{abstract}

\begin{abstract}
Two yellow-pigmented, Gram-negative, rod-shaped bacterial strains, GH1-10 ${ }^{\top}$ and $\mathrm{GH} 29-5^{\top}$, were isolated from greenhouse soils in Korea. 16S rRNA gene sequence analysis indicated that these strains were related to members of the genus Flavobacterium. Strain $\mathrm{GH} 1-10^{\top}$ was most closely related to Flavobacterium psychrolimnae and Flavobacterium denitrificans, with sequence similarities of 95.9 and $95 \cdot 2 \%$, respectively. Strain GH29-5' was most closely related to 'Flavobacterium saliodium', F. denitrificans and Flavobacterium frigoris, with sequence similarities of $94 \cdot 3,92 \cdot 5$ and $92.5 \%$, respectively. The major cellular fatty acids of $\mathrm{GH} 1-10^{\top}$ were iso- $\mathrm{C}_{15: 0}$, summed feature 3 (iso- $\mathrm{C}_{15: 0} 2-\mathrm{OH}$ and/or $\mathrm{C}_{16: 1} \omega 7 \mathrm{c}$ ) and iso- $\mathrm{C}_{17: 0} 3-\mathrm{OH}$, and those of $\mathrm{GH} 29-5^{\top}$ were iso- $\mathrm{C}_{15: 0}$, iso- $\mathrm{C}_{17: 0} 3-\mathrm{OH}$, iso- $\mathrm{C}_{15: 1} \mathrm{G}$ and iso- $\mathrm{C}_{15: 0} 3-\mathrm{OH}$. Both strains contained menaquinone with six isoprene units $(M K-6)$ as the sole quinone. The DNA G $+C$ contents of $\mathrm{GH} 1-10^{\top}$ and $\mathrm{GH} 29-5^{\top}$ were 35 and $39 \mathrm{~mol} \%$, respectively. Based on the phylogenetic and phenotypic data presented, it is concluded that the two bacteria represent two separate novel species of the genus Flavobacterium. The names proposed to accommodate these organisms are Flavobacterium daejeonense sp. nov., with type strain $\mathrm{GH} 1-10^{\top}\left(=\mathrm{KACC} 11422^{\top}=\mathrm{DSM} 17708^{\top}\right)$, and Flavobacterium suncheonense sp. nov., with type strain $\mathrm{GH} 29-5^{\top}\left(=\mathrm{KACC} 11423^{\top}=\mathrm{DSM} 17707^{\top}\right)$.
\end{abstract}

We isolated two yellow-pigmented bacterial strains, GH1$10^{\mathrm{T}}$ and $\mathrm{GH} 29-5^{\mathrm{T}}$, from greenhouse soils in Korea. 16S rRNA gene sequence analysis indicated that these strains represented two novel species of the genus Flavobacterium.

The genus Flavobacterium was proposed by Frankland in 1889. The genus belongs within the CytophagaFlavobacterium-Bacteroides (CFB) group, which is also known as the phylum Bacteroidetes (Ludwig \& Klenk, 2001). Members of the CFB group are widely distributed in nature, particularly in marine environments (Glöckner et al., 1999; Kirchman, 2002). Recently, Flavobacterium species have been isolated from seawater and freshwater, but relatively few have been isolated from soil environments.

\section{Abbreviation: CFB, Cytophaga-Flavobacterium-Bacteroides.}

The GenBank/EMBL/DDBJ accession numbers for the 16S rRNA gene sequence of strains $\mathrm{GH} 1-10^{\top}$ and $\mathrm{GH} 29-5^{\top}$ are $\mathrm{DO} 222427$ and D0222428, respectively.

A table giving the cellular fatty acid content of strains $\mathrm{GH} 1-10^{\top}$ and $\mathrm{GH} 29-5^{\top}$ is available as supplementary material in IJSEM Online.
R2A medium (Difco; Reasoner \& Geldreich, 1985) was used for strain isolation, and the two novel strains were routinely grown at $28^{\circ} \mathrm{C}$. Growth was assessed at 4, 10, 20, 25, 30, 33, 37 and $40^{\circ} \mathrm{C}$, at $\mathrm{pH} 4,5,6,7,8,9$ and 10 , and at $0,1,3,5$ and $7 \% \mathrm{NaCl}$. The isolates were tested for a number of key characteristics by using standard procedures (Smibert \& Krieg, 1994), such as Gram staining, production of catalase, oxidase and indole, Voges-Proskauer reaction, and hydrolysis of agar, casein, DNA, gelatin and starch. Hugh-Leifson medium (Hugh \& Leifson, 1953) was used to test for glucose oxidation/fermentation. CM-cellulose (Sigma) $(0 \cdot 1 \%)$ and Whatman powder CF11 $(0 \cdot 1 \%)$ were used to test for hydrolysis of cellulose; degradation of alginic acid $(0.5 \%$, $\mathrm{w} / \mathrm{v})$, chitin from crab shells $(1 \%$, w/v), egg yolk $(5 \%$, $\mathrm{w} / \mathrm{v})$, pectin $(0.5 \%, \mathrm{w} / \mathrm{v})$ and tyrosine $(0.5 \%, \mathrm{w} / \mathrm{v})$ was also tested. The urease test, absorption of Congo red and production of flexirubin-type pigments were determined by using the methods of MacFaddin (2000), Bernardet et al. (2002) and Reichenbach (1989), respectively. Cell motility was examined by using $1 / 10$-strength R2A medium, and gliding motility was observed by using 
oil-immersion phase-contrast microscopy of the edge of colonies in exponential growth phase. Strains were additionally characterized by using the whole test spectrum of the API 20NE, API 50CH and API ZYM (bioMérieux) systems according to the manufacturer's instructions.

For analysis of fatty acids, the strains were grown at $28{ }^{\circ} \mathrm{C}$ on R2A agar. After $48 \mathrm{~h}$ growth, cells were harvested, and identification of fatty acids was performed by using the standard protocol of the Microbial Identification System (MIDI; Microbial ID). Isoprenoid quinones were analysed by HPLC as described by Groth et al. (1996). DNA G +C contents were determined by using an HPLC-based method as described by Mesbah et al. (1989) using a reversed-phase column (Supelcosil LC-18-S; Supelco).

The 16S rRNA gene sequence was determined by PCR amplification (Kwon et al., 2003) and direct sequencing (Hiraishi, 1992). A phylogenetic tree was generated by using the neighbour-joining algorithm (Saitou \& Nei, 1987).
Colonies of strains $\mathrm{GH} 1-10^{\mathrm{T}}$ and $\mathrm{GH} 29-5^{\mathrm{T}}$ were yellow, convex and round with clear margins. Both strains grew on R2A medium, trypticase soy agar (TSA; Difco) and nutrient agar (NA; Difco), but did not grow on MacConkey agar (Difco). GH1-10 ${ }^{\mathrm{T}}$ grew well on TSA, but GH29- $5^{\mathrm{T}}$ showed only weak growth when subcultured on TSA. Strain GH29$5^{\mathrm{T}}$ showed no colour changes in all tubes of the API $50 \mathrm{CH}$ system as well as for the glucose fermentation reaction in the API 20NE system. Phenotypic characteristics of both strains are given in the species descriptions below and in Table 1 .

Cellular fatty acid analysis showed that strains GH1-10 ${ }^{\mathrm{T}}$ and $\mathrm{GH} 29-5^{\mathrm{T}}$ contained iso- $\mathrm{C}_{15: 0}$ as the most abundant component, present at 23.0 and $29.9 \%$ of the total, respectively. Strain $\mathrm{GH} 1-10^{\mathrm{T}}$ also contained considerable amounts of summed feature $3\left(20.5 \%\right.$; iso- $\mathrm{C}_{15: 0} 2-\mathrm{OH}$ and/or $\left.\mathrm{C}_{16: 1} \omega 7 c\right)$ and iso- $\mathrm{C}_{17: 0} 3-\mathrm{OH}(10 \cdot 7 \%)$. Strain GH29- $5^{\mathrm{T}}$ contained high levels of iso- $\mathrm{C}_{17: 0} 3-\mathrm{OH}(17 \cdot 7 \%)$, iso- $\mathrm{C}_{15: 1} \mathrm{G}(12 \cdot 0 \%)$ and iso- $\mathrm{C}_{15: 0} 3-\mathrm{OH}(11 \cdot 1 \%)$ (see Supplementary Table S1 in IJSEM Online). The fatty acid

Table 1. Phenotypic characteristics of Flavobacterium daejeonense sp. nov., Flavobacterium suncheonense sp. nov. and some related Flavobacterium species

Taxa: 1, F. daejeonense GH1-10 ${ }^{\mathrm{T}}$; 2, F. suncheonense GH29-5 ${ }^{\mathrm{T}}$; 3, F. aquatile; 4, F. denitrificans; 5, F. johnsoniae; 6, F. flevense; 7, F. psychrolimnae; 8, F. xanthum; 9, F. micromati; 10, F. columnare; 11, F. gelidilacus. Data are taken from Bernardet et al. (1996), Holmes et al. (1988), McCammon \& Bowman (2000), Van Trappen et al. (2004, 2005), Yabuuchi et al. (1983) and this study. Symbols: +, positive test; $(+)$, positive test, weak or delayed response; -, negative; $\mathrm{V}$, test results vary between strains; $(\mathrm{v})$, variable among references; ND, no available data.

\begin{tabular}{|c|c|c|c|c|c|c|c|c|c|c|c|}
\hline Characteristic & 1 & 2 & 3 & 4 & 5 & 6 & 7 & 8 & 9 & 10 & 11 \\
\hline \multicolumn{12}{|l|}{ Growth on: } \\
\hline Trypticase soy agar & + & $(+)$ & $(+)$ & + & + & + & + & + & $(+)$ & - & + \\
\hline Nutrient agar & + & + & - & $\mathrm{ND}$ & + & + & + & + & + & - & + \\
\hline Growth at $25^{\circ} \mathrm{C}$ & + & + & + & + & + & + & + & $(+)$ & $(+)$ & + & + \\
\hline Flexirubin-type pigment & - & - & - & + & + & - & - & - & - & + & - \\
\hline Congo red absorption & - & - & - & $\mathrm{ND}$ & $(\mathrm{V})$ & - & - & - & - & + & - \\
\hline Glucose utilization & + & - & $\mathrm{ND}$ & + & + & + & + & + & - & - & - \\
\hline Acid from carbohydrate & + & - & + & - & + & + & - & + & - & - & - \\
\hline \multicolumn{12}{|l|}{ Degradation of: } \\
\hline Gelatin & - & + & (v) & $\mathrm{ND}$ & + & - & - & + & - & + & $\mathrm{V}$ \\
\hline Casein & - & + & + & $\mathrm{ND}$ & + & - & + & + & - & + & + \\
\hline Starch & + & - & (v) & $\mathrm{ND}$ & + & $\mathrm{ND}$ & + & + & - & - & + \\
\hline CM-cellulose & - & - & - & $\mathrm{ND}$ & + & - & - & - & - & - & - \\
\hline Agar & - & - & - & ND & - & + & - & - & - & - & - \\
\hline Alginate & - & - & $\mathrm{ND}$ & $\mathrm{ND}$ & + & - & - & - & - & $\mathrm{ND}$ & - \\
\hline Pectin & - & - & $\mathrm{ND}$ & $\mathrm{ND}$ & + & + & - & - & - & $\mathrm{ND}$ & - \\
\hline Chitin & - & - & - & $\mathrm{ND}$ & + & - & - & - & - & - & - \\
\hline Aesculin & + & - & (v) & $\mathrm{ND}$ & + & + & + & + & + & - & - \\
\hline DNA & - & - & - & $\mathrm{ND}$ & + & - & - & - & - & + & - \\
\hline Tyrosine & - & + & (v) & $\mathrm{ND}$ & + & - & - & - & - & - & - \\
\hline Precipitation on egg-yolk agar & - & + & + & $\mathrm{ND}$ & - & - & - & - & - & + & - \\
\hline$\beta$-Galactosidase activity & + & - & $\mathrm{ND}$ & $\mathrm{ND}$ & + & + & - & - & - & - & - \\
\hline Nitrate reduction & + & - & $\mathrm{ND}$ & + & + & $\mathrm{ND}$ & - & + & - & $\mathrm{ND}$ & - \\
\hline DNA G $+C$ content $(\mathrm{mol} \%)$ & 35 & 39 & 33 & 35 & 34 & 35 & 34 & 36 & 33 & 32 & 30 \\
\hline
\end{tabular}


profiles of the two strains showed only minor variations. Both strains contained menaquinone with six isoprene units (MK-6) as the sole quinone. The DNA G $+\mathrm{C}$ contents of strains $\mathrm{GH} 1-10^{\mathrm{T}}$ and $\mathrm{GH} 29-5^{\mathrm{T}}$ were 35 and $39 \mathrm{~mol} \%$, respectively.

In the phylogenetic tree constructed based on the neighbour-joining algorithm (Saitou \& Nei, 1987), strains GH $1-10^{\mathrm{T}}$ and $\mathrm{GH} 29-5^{\mathrm{T}}$ fell within the radiation of the cluster comprising members of the genus Flavobacterium, but occupied quite different phylogenetic positions within the genus (Fig. 1). The nearly complete $16 \mathrm{~S}$ rRNA gene sequences (about 1410 nucleotide positions) of strains GH1 $-10^{\mathrm{T}}$ and GH29- $5^{\mathrm{T}}$ were compared with those of the type strains of a wide range of related recognized species and of 'Flavobacterium saliodium'. None of the reference taxa had a sequence similarity to the two new isolates above the $97 \%$ recommended cut-off value for the delineation of genomic species (Stackebrandt \& Goebel, 1994). The 16S rRNA gene sequence of strain $\mathrm{GH} 1-10^{\mathrm{T}}$ showed highest similarities to Flavobacterium psychrolimnae LMG $22018^{\mathrm{T}}$ $(95 \cdot 9 \%)$ and Flavobacterium denitrificans $\mathrm{ED}^{\mathrm{T}}(95 \cdot 2 \%)$. Strain GH29-5 $5^{\mathrm{T}}$ showed highest $16 \mathrm{~S}$ rRNA gene sequence similarities to ' $F$. saliodium' AS $1 \cdot 3801(94 \cdot 3 \%)$, F. denitrificans $\mathrm{ED}^{\mathrm{T}}(92 \cdot 5 \%)$ and Flavobacterium frigoris LMG $21922^{\mathrm{T}}(92 \cdot 5 \%)$.
These gene sequence comparisons clearly demonstrated that strains $\mathrm{GH} 1-10^{\mathrm{T}}$ and $\mathrm{GH} 29-5^{\mathrm{T}}$ represent members of the genus Flavobacterium. The fatty acid profiles and other phenotypic characteristics of the two strains further support this conclusion. We therefore suggest that GH1-10 and $\mathrm{GH} 29-5^{\mathrm{T}}$ are the type strains of two novel species, for which the names Flavobacterium daejeonense sp. nov. and Flavobacterium suncheonense sp. nov. are proposed, respectively.

\section{Description of Flavobacterium daejeonense sp. nov.}

Flavobacterium daejeonense (dae.jeon.en'se. N.L. neut. adj. daejeonense pertaining to Daejeon, a city in Korea, from where the type strain was isolated).

Cells are Gram-negative rods $(0.5 \times 2-3 \mu \mathrm{m})$. Growth occurs at $5-35^{\circ} \mathrm{C}, \mathrm{pH} 6-8$ and $0-3 \% \mathrm{NaCl}$. Gliding motility is absent. Colonies are yellow, convex and round with clear margins. Catalase and oxidase tests are positive. Starch and aesculin are degraded, but gelatin, casein, cellulose, agar, alginate, pectin, chitin, DNA, tyrosine and egg yolk are not. Congo red is not absorbed. Flexirubin-type pigments are not produced. Voges-Proskauer reaction is negative. Positive reactions for nitrate reduction, aseculin hydrolysis and

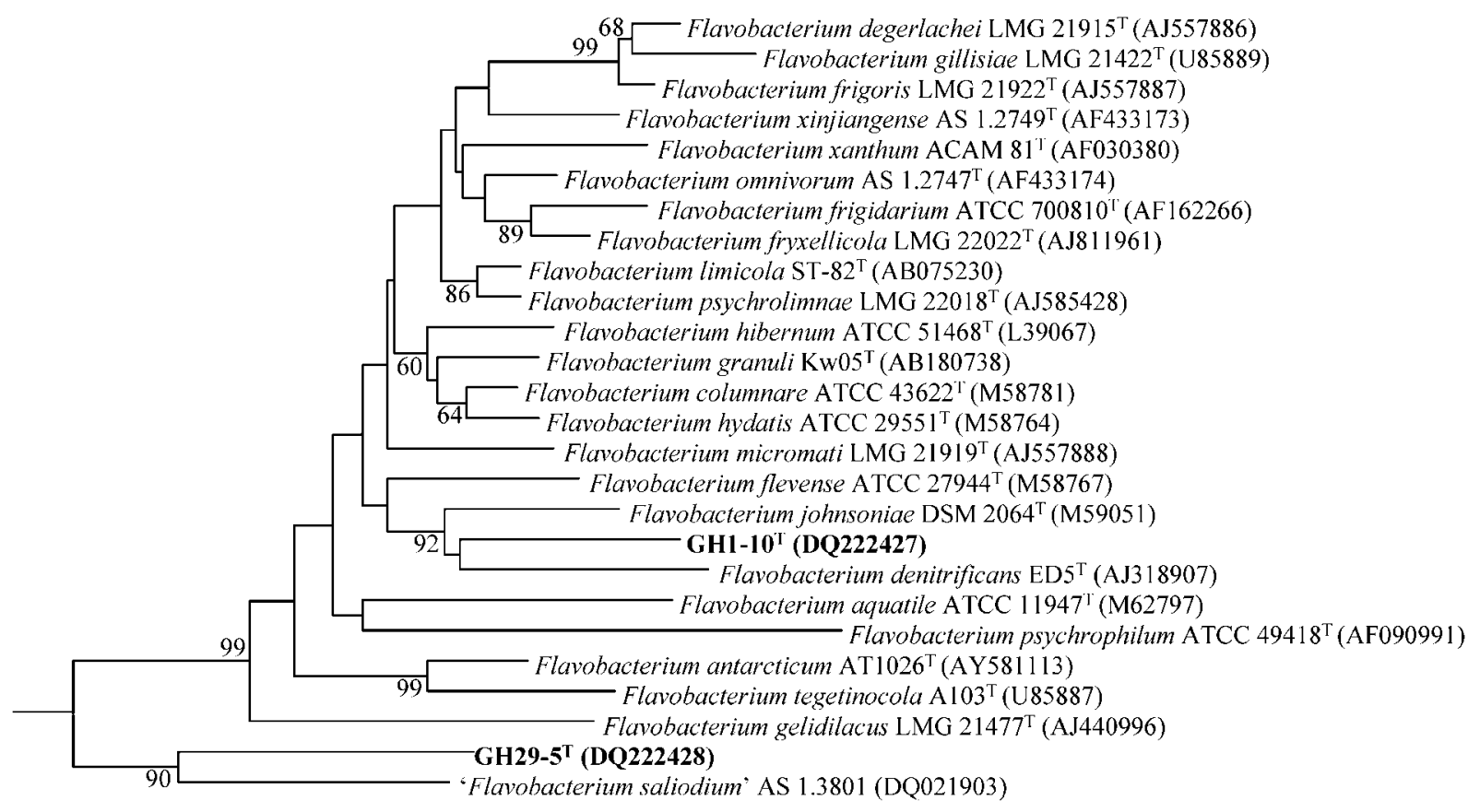

0.02

Fig. 1. Phylogenetic relatedness of strains $\mathrm{GH} 1-10^{\top}, \mathrm{GH} 29-5^{\top}$ and the type strains of Flavobacterium species on the basis of 16S rRNA gene sequence comparison. The dendrogram was generated by using neighbour-joining analysis (Saitou \& Nei, 1987). Numbers at nodes indicate levels of bootstrap support based on a neighbour-joining analysis of 1000 resampled datasets; only values $>60 \%$ are shown. Bar, two substitutions per $100 \mathrm{nt}$. 
$\beta$-galactosidase, but negative reactions for indole production, glucose fermentation, arginine dihydrolase, urease and gelatin hydrolysis (API 20NE). Assimilates D-glucose, L-arabinose, D-mannose and D-maltose, but not D-mannitol, $\mathrm{N}$-acetylglucosamine, potassium gluconate, capric acid, adipic acid, malic acid, trisodium citrate or phenylacetic acid. Enzymic activity is detected for alkaline phosphatase, esterase C4, esterase lipase C8 (weak), leucine arylamidase, valine arylamidase, acid phosphatase, naphthol-AS-BIphosphohydrolase, $\alpha$-galactosidase, $\beta$-galactosidase, $\alpha$-glucosidase and $N$-acetyl- $\beta$-glucosaminidase (API ZYM). No activity is detected for lipase C14, cystine arylamidase, trypsin, $\alpha$-chymotrypsin, $\beta$-glucuronidase, $\beta$-glucosidase, $\alpha$-mannosidase or $\alpha$-fucosidase (API ZYM). Produces acid from $\mathrm{L}$-arabinose, D-xylose, D-galactose, D-glucose, D-fructose, D-mannose, aesculin, D-maltose, D-lactose, D-melibiose, sucrose, inulin and D-raffinose (API 50CH). Major cellular fatty acids are iso- $\mathrm{C}_{15: 0}(23 \%)$, summed feature 3 (iso- $\mathrm{C}_{15: 0} 2-\mathrm{OH}$ and/or $\mathrm{C}_{16: 1} \omega 7 c ; 20.5 \%$ ) and iso- $\mathrm{C}_{17: 0} 3-\mathrm{OH}(10 \cdot 7 \%)$. The sole quinone is $\mathrm{MK}-6$, and the DNA G $+\mathrm{C}$ content is $35 \mathrm{~mol} \%$.

The type strain, GH1- $10^{\mathrm{T}}\left(=\right.$ KACC $\left.11422^{\mathrm{T}}=\mathrm{DSM} 17708^{\mathrm{T}}\right)$, was isolated from greenhouse soil, Daejon city, Republic of Korea.

\section{Description of Flavobacterium suncheonense sp. nov.}

Flavobacterium suncheonense (sun.cheon.en'se. N.L. neut. adj. suncheonense pertaining to Suncheon, a city in Korea, from where the type strain was isolated).

Cells are Gram-negative rods $(0 \cdot 3 \times 1 \cdot 5-2 \cdot 5 \mu \mathrm{m})$. Growth occurs at $15-37^{\circ} \mathrm{C}, \mathrm{pH} 6-8$ and $0-1 \% \mathrm{NaCl}$. Gliding motility is absent. Colonies are yellow, convex and round with clear margins. Catalase and oxidase tests are positive. Gelatin, casein, tyrosine and egg yolk are degraded, but starch, cellulose, agar, alginate, pectin, chitin, aesculin and DNA are not. Congo red is not absorbed. Flexirubin-type pigment is not present. Voges-Proskauer reaction is negative. Positive reaction for gelatin hydrolysis, but negative reactions for nitrate reduction, indole production, glucose fermentation, arginine dihydrolase, urease, aseculin hydrolysis and $\beta$-galactosidase (API 20NE). Does not assimilate all carbohydrates tested (API 20NE). Enzymic activity is detected for alkaline phosphatase, esterase $\mathrm{C} 4$, esterase lipase $\mathrm{C} 8$, leucine arylamidase, valine arylamidase, acid phosphatase, naphthol-AS-BI-phosphohydrolase and $N$-acetyl- $\beta$ glucosaminidase (API ZYM). No activity is detected for lipase C14, cystine arylamidase, trypsin, $\alpha$-chymotrypsin, $\alpha$-galactosidase, $\beta$-galactosidase, $\beta$-glucuronidase, $\alpha$-glucosidase, $\beta$-glucosidase, $\alpha$-mannosidase and $\alpha$-fucosidase (API ZYM). No acids are produced from all the substrates tested (API $50 \mathrm{CH}$ ). Major cellular fatty acids are iso- $\mathrm{C}_{15: 0}$ $(29 \cdot 9 \%)$, iso- $\mathrm{C}_{17: 0} 3-\mathrm{OH}(17 \cdot 7 \%)$, iso- $\mathrm{C}_{15: 1} \mathrm{G}(12 \cdot 0 \%)$ and iso- $\mathrm{C}_{15: 0} 3-\mathrm{OH}(11 \cdot 1 \%)$. The sole quinone is MK-6, and the $\mathrm{G}+\mathrm{C}$ content is $39 \mathrm{~mol} \%$.
The type strain, GH29-5 $5^{\mathrm{T}}\left(=\right.$ KACC $\left.11423^{\mathrm{T}}=\mathrm{DSM} 17707^{\mathrm{T}}\right)$, was isolated from greenhouse soil, Suncheon city, Republic of Korea.

\section{Acknowledgements}

This study was supported by a programme of co-operation between the Rural Development Administration (RDA), South Korea, and DSMZ, Germany.

\section{References}

Bernardet, J.-F., Segers, P., Vancanneyt, M., Berthe, F., Kersters, K. \& Vandamme, P. (1996). Cutting a Gordian knot: emended classification and description of the genus Flavobacterium, emended description of the family Flavobacteriaceae, and proposal of Flavobacterium hydatis nom. nov. (basonym, Cytophaga aquatilis Strohl and Tait 1978). Int J Syst Bacteriol 46, 128-148.

Bernardet, J.-F., Nakagawa, Y. \& Holmes, B. (2002). Proposed minimal standards for describing new taxa of the family Flavobacteriaceae and emended description of the family. Int J Syst Evol Microbiol 52, 1049-1070.

Glöckner, F. O., Fuchs, B. M. \& Amann, R. (1999). Bacterioplankton compositions of lakes and oceans: a first comparison based on fluorescence in situ hybridization. Appl Environ Microbiol 65, 3721-3726.

Groth, I., Schumann, P., Weiss, N., Martin, K. \& Rainey, F. A. (1996). Agrococcus jenensis gen. nov., sp. nov., a new genus of actinomycetes with diaminobutyric acid in the cell wall. Int J Syst Bacteriol 46, 234-239.

Hiraishi, A. (1992). Direct automated sequencing of $16 \mathrm{~S}$ rDNA amplified by polymerase chain reaction from bacterial cultures without DNA purification. Lett Appl Microbiol 15, 210-213.

Holmes, B., Weaver, R. E., Steigerwalt, A. G. \& Brenner, D. J. (1988), A taxonomic study of Flavobacterium spiritivorum and Sphingobacterium mizutae: proposal of Flavobacterium yabuuchiae sp. nov. and Flavobacterium mitzutaii comb. nov. Int J Syst Bacteriol 38, 348-353.

Hugh, R. \& Leifson, E. (1953). The taxonomic significance of fermentative versus oxidative metabolism of carbohydrates by various gram-negative bacteria. $J$ Bacteriol 66, 24-26.

Kirchman, D. L. (2002). The ecology of Cytophaga-Flavobacteria in aquatic environments. FEMS Microbiol Ecol 39, 91-100.

Kwon, S. W., Kim, J. S., Park, I. C., Yoon, S. H., Park, D. H., Lim, C. K. \& Go, S. J. (2003). Pseudomonas koreensis sp. nov., Pseudomonas umsongensis sp. nov. and Pseudomonas jinjuensis sp. nov., novel species from farm soils in Korea. Int J Syst Evol Microbiol 53, 21-27.

Ludwig, W. \& Klenk, H.-P. (2001). Overview: a phylogenetic backbone and taxonomic framework for procaryotic systematics. In Bergey's Manual of Systematic Bacteriology, 2nd edn, vol. 1, pp. 49-65. Edited by D. R. Boone, R. W. Castenholz \& G. M. Garrity. New York: Springer.

MacFaddin, J. F. (2000). Biochemical Tests for Identification of Medical Bacteria, 3rd edn, pp. 424-438. Baltimore: Lippincott Williams \& Wilkins.

McCammon, S. A. \& Bowman, J. P. (2000). Taxonomy of Antarctic Flavobacterium species: description of Flavobacterium gillisiae sp. nov., Flavobacterium tegetincola sp. nov. and Flavobacterium xanthum sp. nov., nom. rev. and reclassification of [Flavobacterium] salegens as Salegentibacter salegens gen. nov., comb. nov. Int J Syst Evol Microbiol 50, 1055-1063. 
Mesbah, M., Premachandran, U. \& Whitman, W. B. (1989). Precise measurement of the $\mathrm{G}+\mathrm{C}$ content of deoxyribonucleic acid by high-performance liquid chromatography. Int J Syst Bacteriol 39, 159-167.

Reasoner, D. J. \& Geldreich, E. E. (1985). A new medium for the enumeration and subculture of bacteria from potable water. Appl Environ Microbiol 49, 1-7.

Reichenbach, H. (1989). Order I. Cytophagales Leadbetter 1974. In Bergey's Manual of Systematic Bacteriology, vol. 3, pp. 2011-2013. Edited by J. T. Staley, M. P. Bryant, N. Pfenning \& J. G. Holt. Baltimore: Williams \& Wilkins.

Saitou, N. \& Nei, M. (1987). The neighbor-joining method: a new method for reconstructing phylogenetic trees. Mol Biol Evol 4, 406-425.

Smibert, R. M. \& Krieg, N. R. (1994). Phenotypic characterization. In Methods for General and Molecular Bacteriology, pp. 607-654. Edited by P. Gerhardt, R. G. E. Murray, W. A. Wood \& N. R. Krieg. Washington, DC: American Society for Microbiology.
Stackebrandt, E. \& Goebel, B. M. (1994). Taxonomic note: a place for DNA-DNA reassociation and 16S rRNA sequence analysis in the present species definition in bacteriology. Int J Syst Bacteriol 44, 846-849.

Van Trappen, S., Vandecandelaere, I., Mergaert, J. \& Swings, J. (2004). Flavobacterium degerlachei sp. nov., Flavobacterium frigoris sp. nov. and Flavobacterium micromati sp. nov., novel psychrophilic bacteria isolated from microbial mats in Antarctic lakes. Int J Syst Evol Microbiol 54, 85-92.

Van Trappen, S., Vandecandelaere, I., Mergaert, J. \& Swings, J. (2005). Flavobacterium fryxellicola sp. nov. and Flavobacterium psychrolimnae sp. nov., novel psychrophilic bacteria isolated from microbial mats in Antarctic lakes. Int J Syst Evol Microbiol 55, 769-772.

Yabuuchi, E., Kaneko, T., Tano, I., Moss, C. W. \& Miyoshi, N. (1983). Sphingobacterium gen. nov., Sphingobacterium multivorum comb. nov., Sphingobacterium mizutae sp. nov., and Flavobacterium indologenes sp. nov.: glucose-nonfermentation Gram-negative rods in CDC groups IIK-2 and Iib. Int J Syst Bacteriol 33, 580-598. 